\title{
Anglo-Saxon Leechbooks
}

\author{
Lesley Smith
}

Curator, Tutbury Castle, Tutbury, UK

\section{Correspondence to}

Ms Lesley Smith, Tutbury Castle, Tutbury, Staffordshire

DE13 9JF, UK;

info@tutburycastle.com

Received 22 July 2011

Accepted 22 July 2011

\section{Medical texts}

For scholars of early medicine there are copious numbers of Mediterranean texts to provide clear evidence of practice, both surgical and medical, in the ancient world. Medical texts appeared in Latin or Greek, with the exception of the AngloSaxons who wrote medical texts in their own tongue as well as in Latin.

Research in the Anglo-Saxon period of Britain's written medical history is considerably challenging as there is so little evidence. Texts that do exist give a fascinating insight into medical and magical belief, both absolutely bound together in a society that was constantly aware of how close death could be. Prior to the 9th century, there are no surviving medical documents in Old English.

The two main works that exist are at opposite ends of the medically trained scale. The first is Bald's Leechbook. This is not a work about leeches but a medical handbook; the word "leech" in the Anglo-Saxon language translates to "doctor" and many believe that the animal was named after the practitioner rather than the other way round, as leeches were used so extensively in healing (and still are).

We don't know who Bald was but know his scribe's name from the statement: "Bald owns this book which he ordered Cild to compile".

The manuscript is carefully written and made up of descriptions of various ailments and suggested cures. Latin is found in various places in the text. It is clearly the work of an educated person with some medical knowledge.

The second work considered of great importance is the Lacnunga, which is the Anglo-Saxon word for "remedies" and seems to be written by compilers with little medical knowledge and a poor education compared to Bald. Comparison also reveals a poor understanding of Latin and Old English in the Lacnunga, which provides us with a really valuable view of medical tradition among untrained medical practitioners.

Both works do contain strands of Roman and Greek medicine, but it would be quite wrong to assume they are just poor re-hashed versions of the ancient medical philosophers, such as Galen or Hippocrates. There are Anglo-Saxon traditions present that have a unique style and content. Spells and other forms of magic, including charms and amulets, feature throughout both works. It is hardly surprising to discover that AngloSaxons, like the rest of humanity, wanted to control fertility and to heal women suffering with gynaecological conditions.

\section{Gynaecological conditions}

Bald's Leechbook has a table of contents, part of which records: "Medicine for obstruction of Women's genitalia and for all infirmities of Women". If this seems rather general, there are also specific conditions listed: "... if a woman cannot urinate, and if a woman cannot be properly cleansed (afterbirth), and for haemorrhage in a woman".

These conditions are all recognisable to the modern observer; however, others are vaguer such as: "If a woman suddenly becomes silent" and "if you wish a woman to have a child or birth a bitch cub". I am afraid I cannot throw any light on the birthing of a bitch cub, being unsure if the treatment is interchangeable between human and animal medicine and not necessarily a derogative term for a female child.

Food plays a large part in the pharmacology, served with a range of herbs and spices seen almost constantly in medical texts for thousands of years. An example of one "cure" shows a belt and braces approach: "For a child who will not be born" a meal is offered of wild parsnip boiled in milk and water. Meanwhile the women's thigh was bound up against her genitalia with herbs of henbane and coriander in a sack. This combination of internal and external herbal treatment is also fairly common.

One of the commonest herbal treatments for gynaecological problems is pennyroyal as is henbane. Fenugreek seed and root of marshmallow are used in various forms. Mugwort seems to be considered to be the single most useful herb for healing women, particularly for difficulties concerning the womb. 


\section{Magical charms and spells}

Medical magical components are always fascinating and worth quoting in part of this article. This charm from the Lacnunga is for a "pregnant woman who does not appear to be carrying well, as the child appears malnourished in her womb" (deduced presumably from her size): "Go to the grave of a dead person and step three times over the grave and say these words three times: This be the remedy for me for the loathsome late birth; this be the remedy for the grievous childbirth birth; this be a remedy for me for the loathsome imperfect birth". Black wool and grave mould form part of the continuation of the spell.

The number three is magical as it is rooted in the Christian Holy Trinity and so appears often in Christian narrative charms as well as in spells written on parchment carried on the body or carved into rings.

The mulberry tree, sometimes linked with fertility, appears as a treatment for menstrual flux; combing the hair under a mulberry tree with a comb, unused by anyone else, was recommended.

A dead hare, dried and scraped, offered in a potion to the husband and wife would ensure a boy child according to the text. There is also a clear warning that if only the woman drinks the potion then the child would be "an androgyne, that is as nothing, neither man nor woman", this statement demonstrating knowledge of hermaphrodites in Anglo-Saxon society.

Finally, to sex a child in the womb the texts suggest the medical practitioner offer the pregnant woman a lily or a rose; if she first reaches for the rose, a girl, the lily, a boy.

Other than the ghoulish spells and use of animals in what we would now consider utterly cruel ways, there is a sense in the texts of little surgical intervention and a rather gentle form of treating the human body compared with some of the positively barbaric treatments in the medieval period.
There is no question that we only have a glimpse of formed medical thinking in Anglo-Saxon times, but at the root of these works is rational thinking and practical medicine.

\section{About the author}

Lesley Smith is currently a postgraduate student in the Centre for the History of Medicine of the University of Birmingham, where she is developing a $\mathrm{PhD}$ in obstetrics and gynaecology in early modern Britain. She holds an honorary degree for "services to history". She makes 200-300 public appearances a year and also works as a TV historian in the UK and abroad including the USA. Lesley is also Curator of Tutbury Castle in Staffordshire and is a member of the Society of Apothecaries of London and the Society of Medical Writers. She has recently been appointed a Fellow of the Society of Antiquaries of Scotland.

\section{Acknowledgement}

The author would like to thank Dr G Williams, British Museum, London, UK for his help and advice.

Competing interests None.

Provenance and peer review Commissioned; internally peer reviewed.

\section{Bibliography}

1 Cockayne TO. Leechdoms, Wortcunning and Starcraft of Early England. Published by the authority of the Lords Commissioners of Her Majesty's Treasury, under the direction of the Master of the Rolls. London, UK: Longmans, Green, Reader \& Dyer, 1866.

2 Wright CE. Bald's Leechbook. Copenhagen, Denmark: Rosenkilde \& Bagger, 1955.

3 Cameron ML. Anglo-Saxon Medicine. Cambridge, UK: Cambridge University Press, 1993.

4 Grattan JHG, Singer C. Anglo-Saxon Music and Medicine. Illustration specially from the semi-pagan text, Lacnunga. Oxford, UK: Oxford University Press, 1952. 